\title{
Relationship between age-sex classes and prevalence of Giardia spp. and Blastocistys spp. in black and gold howler monkeys inhabiting fragmented forests
}

\author{
Rumesilda Eliana AlegreE ${ }^{1 *}$, María Sol Gennuso², Francisca Milano', and Martin Kowalewski² \\ ${ }^{1}$ Laboratorio de Biología de los Parásitos, Grupo de Investigación BioVyP. Facultad de Ciencias Exactas y Naturales y Agrimensura, \\ Universidad Nacional del Nordeste. Av. Libertad 5470, 3400, Provincia de Corrientes, Argentina. Email: rumeeliana@gmail.com \\ (REA), mfmilano@yahoo.com.ar (FM). \\ ${ }^{2}$ Estación Biológica Corrientes MACN, CONICET. Ruta Pcial. 8 s/n 3401-San Cayetano Provincia de Corrientes, Argentina. Email: \\ solgennuso@gmail.com (SG), martinkow@gmail.com (MK). \\ *Corresponding author
}

Studies have shown that as age increases, parasitism could also be more frequent, on the other hand, the lack of immunity can increase the risk of infection in younger individuals. Regarding sex, there is a general tendency for males to be more parasitized than females, in the case of primates, this is related to the effort made by males into attaining and maintain a high rank, implying high levels of testosterone, a hormone with immunosuppressive effects. Immunosuppressive effects of stress hormones can also increase susceptibility in dominant or subordinate individuals, nevertheless, in a study, the level of exposure to parasites seems to be more important than the immunosuppressive effects of stress in explaining why dominant females have more infections from directly transmitted parasites. In this study, we investigated the relationship between the prevalence of Giardia spp. and Blastocystis spp. and the categories of age and sex in black and golden howler monkeys (Alouatta caraya) of Argentina. We analyzed 375 fecal samples from 27 individuals (juveniles and adults of both sexes), using microscopy and techniques of flotation and sedimentation. To analyze the relationship between age, sex, and infection prevalence, a Generalized Linear Mixed Model was used. In adults, the prevalence of infection was $78.5 \%$ while in juveniles, all individuals (100 \%) were infected with both protozoa. Males had a infection prevalence $84.6 \%$, in females it was $92.8 \%$. When comparing infection prevalence between ages and between sexes, no significant differences were found $(P>0.05)$. Research suggests that parasite infection rates may be influenced by specific form of transmission, in this sense, these protozoa, are transmitted through ingestion of cysts which are infectious immediately after defecation has occurred. On the other hand, all members of the group tend to defecate simultaneously, leaving all the members of the group exposed to infection. Therefore, we suggest that physiological or behavioral factors do not appear to be important in the risk of protozoan infection.

Algunos estudios han demostrado que a medida que aumenta la edad, el parasitismo también podría aumentar, por otro lado, la falta de inmunidad puede incrementar el riesgo de infección en individuos más jóvenes. En cuanto al sexo, existe una tendencia general a que los machos estén más parasitados que las hembras, en el caso de los primates, esto está relacionado al esfuerzo que realizan los machos para alcanzar y mantener un alto rango, implicando niveles elevados de testosterona, una hormona con efectos inmunosupresores. Efectos inmunosupresores de las hormonas del estrés también pueden incrementar la susceptibilidad en individuos dominantes o subordinados, sin embargo, en un estudio, el nivel de exposición a parásitos parece ser más importante que los efectos inmunosupresores del estrés para explicar por qué las hembras dominantes tienen más infecciones por parásito. En este estudio, investigamos la relación entre la prevalencia de Giardia spp. y Blastocystis spp. y las categorías de edad y sexo en monos aulladores negros y dorados (Alouatta caraya) de Argentina. Se analizaron 375 muestras fecales de 27 individuos (juveniles y adultos de ambos sexos), mediante microscopia y técnicas de flotación y sedimentación. Para analizar la relación entre edad, sexo y prevalencia de infección se utilizó un Modelo Lineal Generalizado Mixto. En adultos, la prevalencia de infección fue del $78.5 \%$, mientras que, en los juveniles, todos los individuos (100\%) estuvieron infectados con ambos protozoos. Los machos tuvieron una prevalencia de infección de $84.6 \%$ y las hembras $92.8 \%$. Al comparar la prevalencia de infección entre edades y entre sexos, no se encontraron diferencias significativas $(P>0.05)$. Investigaciones sugieren que las tasas de infección parasitaria pueden ser afectadas por la forma de transmisión, en este sentido, estos protozoos, se transmiten a través de la ingestión de quistes, lo cuales son infecciosos inmediatamente después de la defecación. Por otro lado, todos los miembros del grupo tienden a defecar simultáneamente, contribuyendo a la presencia de áreas contaminadas con heces, dejando a todos los miembros del grupo expuestos a la infección. Por lo tanto, sugerimos que los factores fisiológicos o de comportamiento no parecen ser importantes en el riesgo de infección por protozoos.

Keywords: Endoparasites; intrinsic factors; non-human primates; prevalence of infection; protozoa. 


\section{Introduction}

Given that deforestation, habitat modification, and degree of human contact with wild animals are increasing exponentially in most parts of the world (Chapman et al. 2006), several studies have explored how these factors may impact on parasite infection risk in non-human primates (Clarke et al. 2002; Kowalewski and Gillespie 2009; Cristóbal-Azkarate et al. 2010). However, the studies focusing on the relationship between parasite prevalence and richness with life history variables such as individual age and sex in wild primates are scarce (Maclntosh et al. 2010; Friant et al. 2016).

The age of an individual has been reported to differentially affect rates of parasitic transmission in several vertebrate taxa including fish, birds, bats, rodents, and nonhuman and human primates (Krasnov et al. 2006; Plowright et al. 2008; Maclntosh et al. 2010). In the case of wild primates, studies have shown that when age increases, parasitism could also increase if, for example, larger-bodied individuals occupy more space, require more resources and have contact with contaminated foods and substrates disproportionately (Hudson and Dobson 1997). In fact, studies of non-human primates found that adults had higher helminth parasite infection rates than juveniles (e. g., Cebus capucinus, Parr et al. 2013; Alouatta pigra, Eckert et al. 2006; Mandrillus sphinx, Setchell et al. 2007). On the other hand, lack of acquired immunity in younger individuals may increase risk of parasitism in juveniles (Hudson and Dobson 1997), given that younger individuals require constant exposure to pathogens to stimulate their immune system to develop antibodies to limit subsequent pathogenic infections during adulthood (Lloyd 1995). For example, a study in Mexico reported that juveniles Alouatta palliata showed a 1.6-fold higher helminth and protozoan parasite prevalence than adults (Stoner and González Di Pierro 2006). However, other studies reported no differences between helminth and protozoa parasite infection and age classes (e. g., A. palliata, Maldonado-López et al. 2014; A. pigra, Trejo-Macías and Estrada 2012; Colobus vellerosus, Teichroeb et al. 2009).

Regarding sex, parasitism tends to be more common in males than in females across vertebrate taxa, including humans (Klein 2004; Habig and Archie 2015). Males generally invest most of their effort into attaining and maintaining high rank and central positions in non-human primate species (Zuk and Stoehr 2002). In this regard testosterone facilitate the achievement of a high rank but there are a number of costs imposed by elevated levels of this hormone, such as immunosuppressive effects, increasing the risk of acquiring parasitic infections (tradeoffs hypothesis; Muehlenbein and Bribiescas 2005): This idea was tested in a study on adult male chimpanzees (Pan troglodytes) at Ngogo, Uganda, where high ranking males had higher testosterone levels and an increased intestinal helminth burden but not protozoan, when compared to lower male ranking animals (Muehlenbein and Watts 2010). In addi- tion, studies in non-human primates, determined that immunosuppressive effects of stress hormones also could increase susceptibility in either dominant or subordinate individuals depending on species-typical dynamics and hierarchical stability (stress-response hypothesis; Cavigelli and Caruso 2015; Sapolsky 2005). Nevertheless, in Japanese macaques, Macaca fuscata, for example, socially mediated exposure seems to be more important than the immunosuppressive effects of stress in explaining why dominant females have more infections from directly transmitted parasites (Maclntosh et al. 2012). These studies, therefore, show that the relationship between infection patterns and intrinsic factors of the host need further research (Nunn and Altizer 2006) and consider that infection patterns largely depend on the level of exposure of the host to the infectious stages of the parasites, to the physiological factor, and the social dynamics of the group studied. For the first time, we investigated the relationship between Giardia spp. and Blastocystis spp. prevalence and age and sex categories in groups of black and gold howler monkeys (Alouatta caraya) that inhabit fragmented forests in Northern Argentina. Field studies conducted on wild populations of $A$. caraya in Argentina have shown that zoonotic protozoa as Giardia spp. and Blastocystis spp. are present and prevalent in wild black and gold howlers, therefore, these protozoa are a natural component of the howler parasite communities (Venturini et al. 2003; Kowalewski et al. 2011; Milozzi et al. 2012). These protozoa have a direct life cycle and are also the most commonly reported parasite in humans and both wild and domestic animals (dogs, cats, sheep, goats, cows, pigs, horses, among others), in both cases, transmission can occur through ingestion of infective stages (cysts), and human infection is associated with poor sanitary conditions, contact with animals and consumption of contaminated food or water (Godoy et al. 2004).

\section{Materials and Methods}

Study site and studied groups. The A. caraya groups studied inhabit extensions of semideciduous gallery forests around the Estación Biológica Corrientes and San Cayetano Provincial Park (of 78 ha; $-27^{\circ} 33^{\prime} 09.5^{\prime \prime} \mathrm{S},-58^{\circ} 40^{\prime} 48.2^{\prime \prime} \mathrm{W}$ ) in the northwest of Corrientes province in Argentina (Figure 1a). These forests have been strongly modified by logging, burning and the presence of livestock, and households are distributed throughout this rural site (Kowalewski et al. 2011). The climate is subtropical, with an average annual temperature of $21^{\circ} \mathrm{C}$ and an average annual precipitation of 1,200 mm (Rumiz et al. 1986). Rains increase slightly towards the spring and summer seasons (September to December).

Fecal samples were collected from 27 individuals (13 juveniles and 14 adults) of both sexes (13 males and 14 females) belonging to four groups of howler monkeys. A subset of adult individuals was sampled, and all juvenile individuals. Figure $1 \mathrm{~b}$ depicts the home range of the four study groups. 

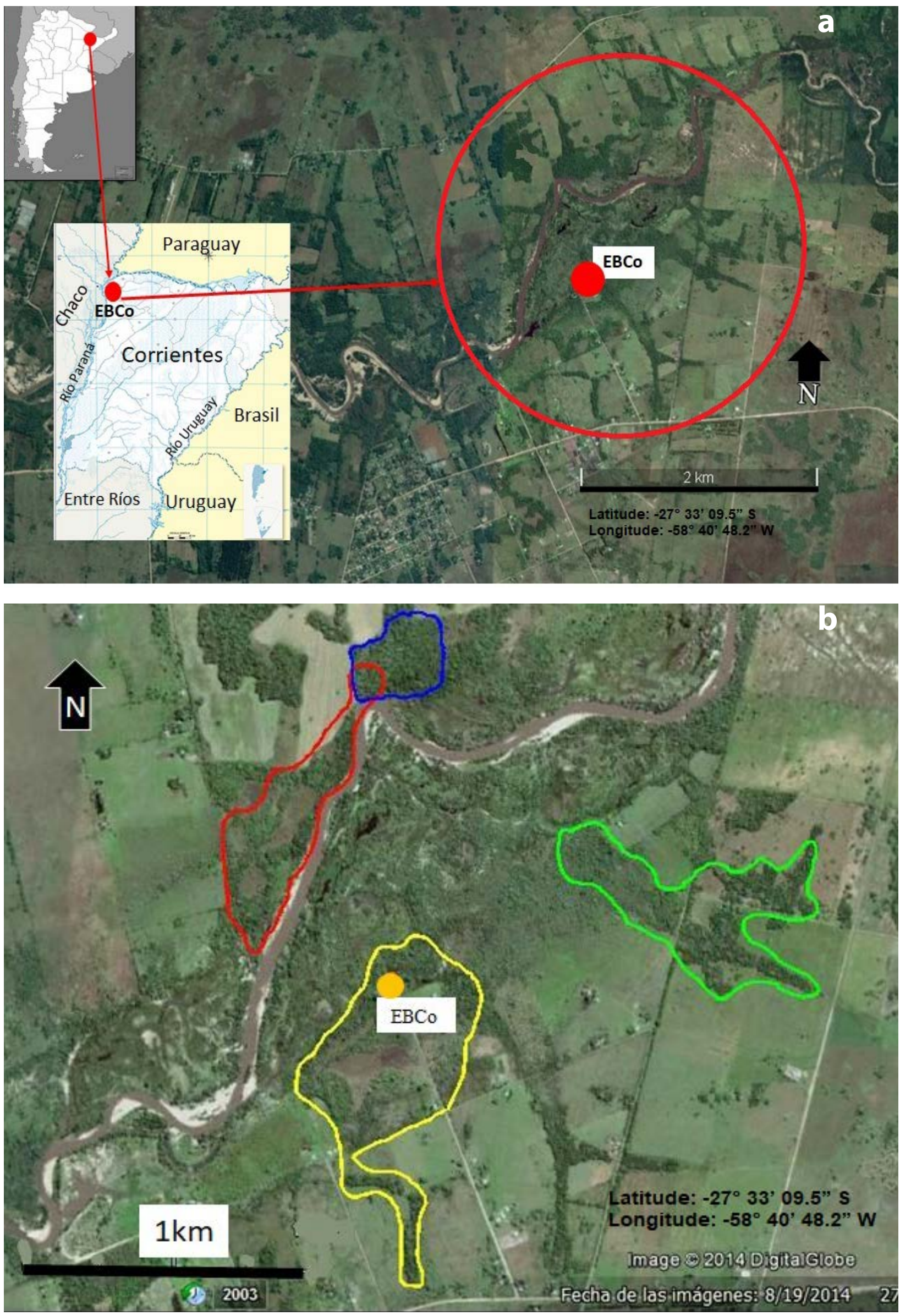

Figure 1. a) Location of area of study in Corrientes, Argentina and b) Area of action of the four studied groups. Blue (group 1), red (group 2), yellow (group 3), green (group 4). 
We categorized juveniles in two age categories: category 1 (from 1 to 2.5 years of age) and category 2 (more than 2.5 to 4 years of age). The age-sex category composition of each of the study groups is in Table 1.

Sample collection and examination. Fecal samples were monthly collected during the morning between August 2014 and September 2015, immediately after defecation to minimize the risk of contamination. Only the central portion of the fecal sample was taken using disposable wooden spatulas. Samples were stored individually in 20 $\mathrm{ml}$ flasks with $10 \%$ formalin and each flask was shaken to homogenize the sample with formalin (Gillespie 2006; Gillespie et al.2008) and then labeled and stored with the date of collection, observer, location and identification of individuals.

Samples were examined in the Laboratorio de Biología de los Parásitos of the Facultad de Ciencias Exactas y Naturales y Agrimensura, during March-December 2017, using microscopy and techniques of flotation (Sheather's solution, D = 1.27; Milozzi et al. 2012) and sedimentation (1g of feces), as per Gillespie (2006) to ensure the collection of cysts of both protozoa (Figure 2a, 2b). In each technique, slides $(18 \mathrm{~mm} \times 18 \mathrm{~mm}$ ) were examined under a stereoscopic magnifying glass (Olympus $\mathrm{CH} 30$; $x 400$ magnification), previously colored with a drop of Lugol's solution; all samples were examined in duplicate.

Data analysis. We described parasite infections in terms of prevalence of infection. Prevalence is the proportion of individuals hosts sampled infected with a particular parasite species (Stuart and Strier 1995; Bush et al. 1997; Gillespie 2006).

To analyze the relationship between age, sex and infection prevalence, a Generalized Linear Mixed Model (GLMM) was used with Gaussian family and link function "Identity", which considered prevalence $(0.5 \pm 0.06)$ as a variable response and age (with three levels: juvenile 1, juvenile 2 , adult) and sex (with two levels: male, female) as fixed effects. Additionally, the individual nested in group was considered as a random effect. The adjustment of the model was evaluated using a maximum likelihood ratio test (LRT) where we compared models with variations in a fixed effect to take

Table 1. Distribution of the number of individuals according to sex and age category in each studied group in Corrientes, Argentina.

\begin{tabular}{|c|c|c|c|c|c|}
\hline & & \multicolumn{4}{|c|}{ Groups } \\
\hline & & 1 & 2 & 3 & 4 \\
\hline \multicolumn{2}{|c|}{ Total (Individuals) } & 6 & 6 & 8 & 7 \\
\hline \multirow[t]{2}{*}{ Adults } & Males & 1 & 2 & 2 & 1 \\
\hline & Females & 2 & 2 & 2 & 2 \\
\hline \multirow[t]{4}{*}{ Juveniles } & Males category 1 & - & 1 & 2 & 1 \\
\hline & Males category 2 & 1 & 1 & - & 1 \\
\hline & Females category 1 & 1 & - & 1 & 1 \\
\hline & Females category 2 & 1 & - & 1 & 1 \\
\hline
\end{tabular}

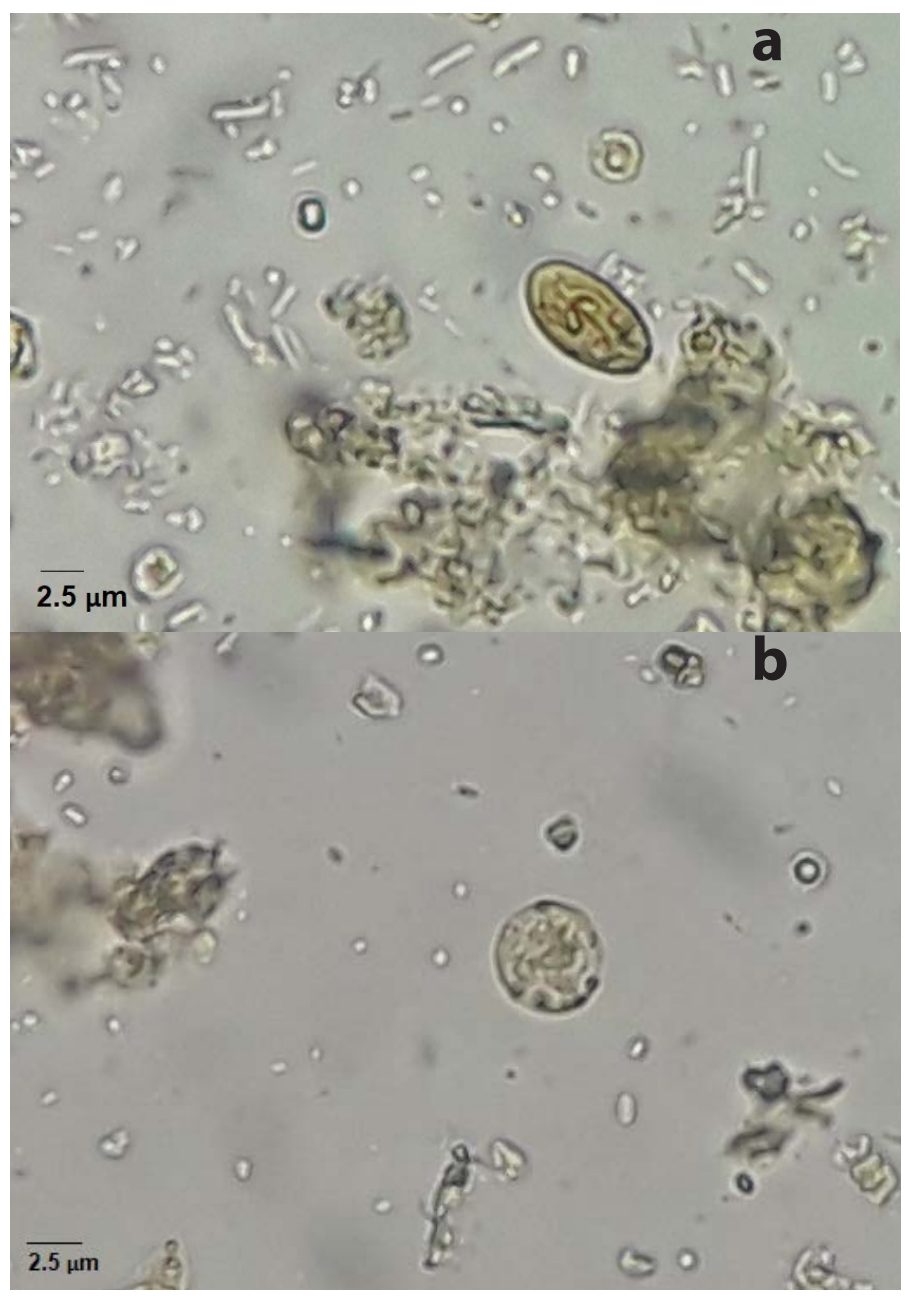

Figure 2. a) Cyst of Giardia spp. and b) Cyst of Blastocystis spp.

into account all the comparisons the random effects are the same (individual nested in group; Bolker et al. 2009). All statistical analyses were performed in $\mathrm{R}$ through the R-studio platform, version 3.2.1 (R Core Team 2016). Statistical significance was set at 0.05 for all interpretations.

\section{Results}

A total of 375 samples were collected, with at least three samples (of different days) per individual per month from 27 individuals ( 13 juveniles and 14 adults), of both sexes (13 males and 14 females) belonging to four groups of howler monkeys.

Parasite prevalence for both protozoan taxa was $88.9 \%$ (24/27). Of the 27 individuals analyzed, we found Giardia spp. infection prevalence to be $81.4 \%(22 / 27)$ and Blastocystis spp. infection prevalence to be $77.7 \%(21 / 27)$.

In adults, infection prevalence was $78.5 \%(11 / 14)$ while in juveniles, all individuals (juveniles 1 and juveniles $2 ; 100 \%)$ seemed to be infected with both protozoa. Males had a prevalence of general infection 84.6 $\%(11 / 13)$ and females had a $92.8 \%(13 / 14$; Table 2$)$. No significant effects of age or sex on prevalence was found as the model selected by LRT was null $(P>0.05$ for sex and age; Figure $3 a, 3 b$ ). 
Tabla 2. Prevalence of infection according to sex/age categories in four groups of $A$. caraya in Corrientes, Argentina ( $n=$ number of Individuals analyzed).

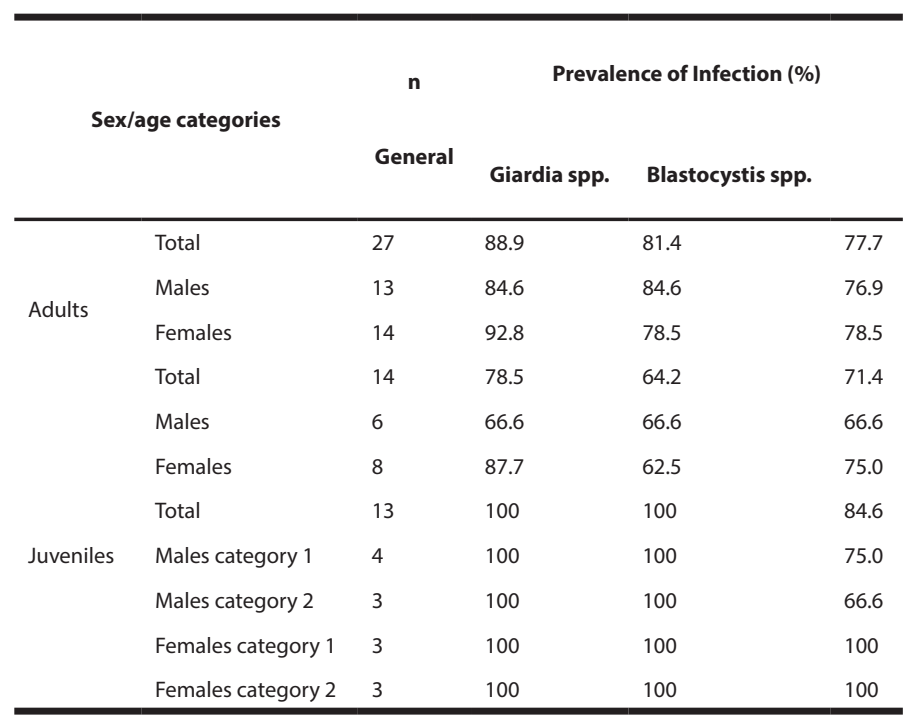

\section{Discussion}

The goal of this research was to explore if Giardia spp. and Blastocystis spp. protozoa parasite infection rates (estimated through infection prevalence) were affected by sex-age in four groups of black and gold howler monkeys (A. caraya) living in forest fragments. Our results suggest that infection prevalence of these protozoans is not affected by these biological factors. These findings are consistent with other studies that also have examined whether host intrinsic traits (age-sex) affect infection gastrointestinal parasites in primates. For example, a study based on 982 stool specimens collected from adult and juvenile individuals from a multimale-multifemale social group of red-capped mangabeys (Cercocebus torquatus) in Nigeria, shows that the acquisition of protozoan infections did not vary according to host traits (Friant et al. 2016). Other studies, conducted over 6 to 7 months by Vitazkova and Wade (2007) and Trejo-Macías and Estrada (2012), based on < 200 fecal samples, did not find significant differences in helminth and protozoan parasite prevalence among adults, juveniles, and infants. On the other hand, Stoner and González Di Pierro (2006) reported that juveniles from three groups showed a 1.6-fold higher helminth and protozoan parasite prevalence than adult howler monkeys (A. pigra) in Montes Azules, México. In short, these set of studies indicate, that there is a general tendency for protozoa to be acquired in a uniform way in primate groups.

Recent research suggests that parasite infection rates may be influenced by specific form of transmission of different parasites (Día 2001; Nunn and Altizer 2006). Then, transmission of these protozoa may occur through ingestion of infective stages (cysts) that do not require develop in the external environment for days to months before they become infective like helminths (Freeland 1980), thus, they are immediately infective once defecation has occurred and can survive in the environment for weeks or months
(Godoy et al. 2004). Moreover, all members in social group tend to defecate simultaneously in their trees after periods of resting (Gilbert 1997; Kowalewski and Zunino 2005), this defecation pattern contributes to the presence of areas of vegetation (latrines) contaminated with clumped feces (potential sources of infection) within the home range of howler groups (Van Belle and Estrada 2006) leaving all members of the group exposed to infection. Therefore, we suggest that physiological or behavioral factors related to the risk of parasitic infection (i. e., that tend to vary according to age and sex in primates) do not appear to be important in the risk of protozoan infection.

It is noteworthy that in our study a high general prevalence of infection was found (88.9\%), that is, 24 out of 27 individuals presented at least one or both protozoa. Our study area is under continued deforestation due to selective
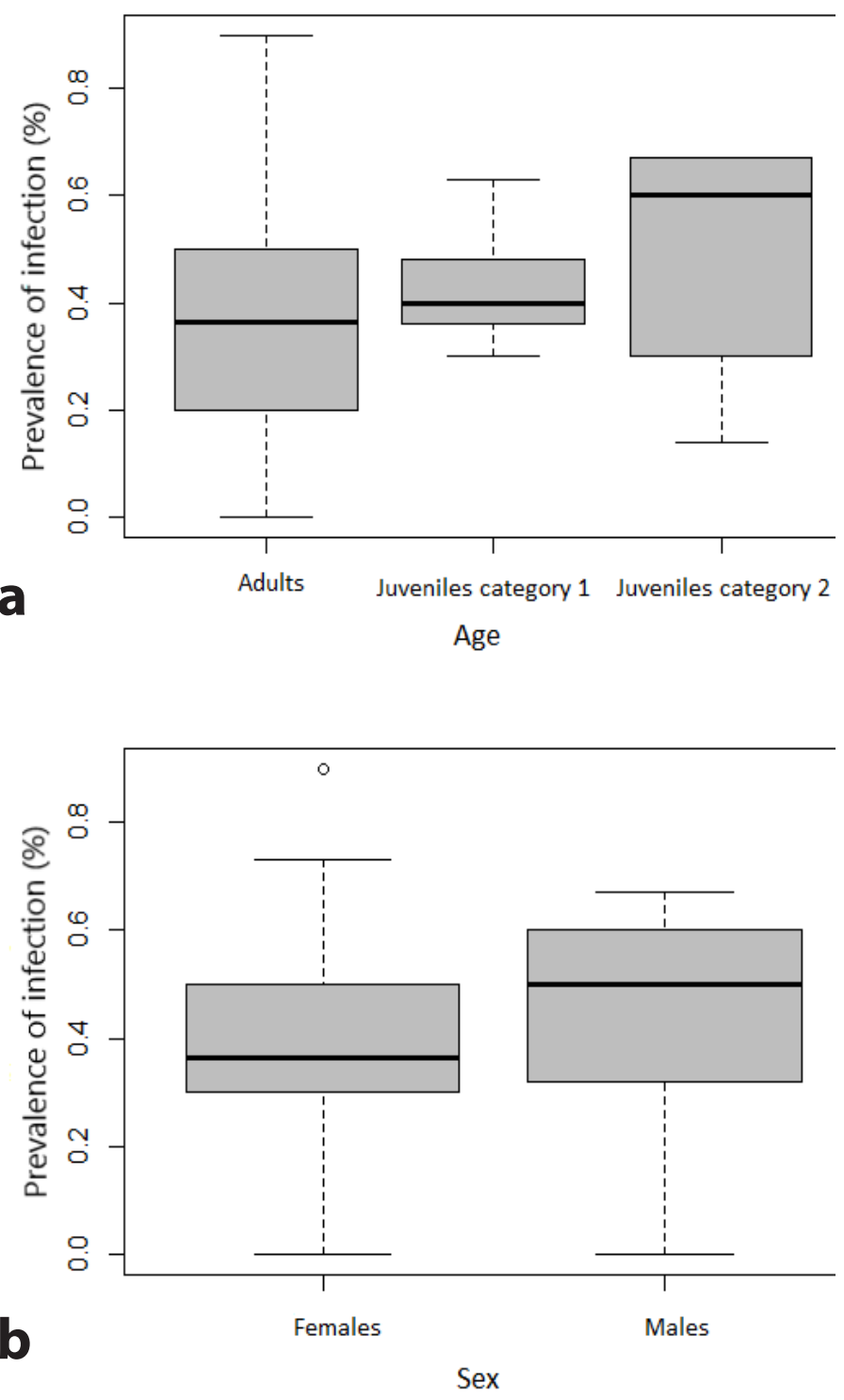

Figure 3. Box plots showing infection prevalence according to age (a) and sex (b) in Alouatta caraya. Median (black line), interquartile ranges (rectangle) and minimum and maximum values (whiskers). 
logging and cattle ranching, such levels of deforestation therefore, decrease habitat size, forcing all howler monkeys to descend to the ground and cross from fragment to fragment looking for supplemental food resources (Zunino et al. 2007) potentially increasing contact with parasites on the ground and in small water bodies (Kowalewski and Gillespie 2009). Additionally, cattle enter into the forest fragments opening trails and defecating along them, also, drink and defecate in streams where as well black and gold howlers drink water, thus increasing the chances of infection in the entire population (Kowalewski et al. 2011). These forest systems may explain our high infection rates for the study protozoans (Bublitz et al. 2015).

Although hypotheses are established that predict possible biases in wild primate populations in relation to intrinsic variables of the host such as sex and age, it is important to consider that host-parasite relationships are highly specific and vary among populations (Hudson and Dobson 1997). Therefore, we consider that studies designed to examine age-sex effects need to consider other potential infection risk factors, such as habitat disturbance (e. g., logging rates, Gillespie and Chapman 2008), parasite life history and transmission, especially in non-human primate populations that are constantly subjected to the reduction of their habitats (Chapman et al. 2006).

\section{Acknowledgments}

We are grateful to all the field assistants who helped us with sample collection, as well as to the collaborators and people at San Cayetano, and technicians from Estación Biológica Corrientes (MACN-CONICET). We thank S. Kuthyar for helping with the English revision and by for their comments and discussion of this manuscript. This study was financed by PI16F/006 SGCyT UNNE, the American Society of Mammalogists (SG), and Consejo Nacional de Investigaciones Científicas y Técnicas de Argentina (SG, MB, RP, MR, MK). This research complied with the current laws and permits of Argentina and adhered to the American Society of Primatologists Principles for the Ethical Treatment of Primates. MK is a current member of CIC-CONICET.

\section{Literature cited}

Bolker, B. M., M. E. Brooks, C. J. Clark, S. W. Geange, J. R. Poulsen, M. H. Stevens, And J. S. White. 2009. Generalized linear mixed models: a practical guide for ecology and evolution. Trends in Ecology and Evolution 2:127-135.

Bublitz, D. C., P. C. Wright, F. T. Rasambainarivo, S. J. ArrigoNelson, J. R. Bodager, and T. R. Gillespie. 2015. Pathogenic enterobacteria in lemurs associated with anthropogenic disturbance. American Journal of Primatology 77:330-337.

Bush, A. O., K. D. Lafferty, J. M. Lotz, And A. W. Shostak. 1997. Parasitology meets ecology on its own terms: Margolis et al. revisited. Journal of Parasitology 83:575-583.

Cavigelli, S. A., and M. J. Caruso. 2015. Sex, social status and physiological stress in primates: the importance of social and glucocorticoid dynamics. Philosophical Transactions of the Royal Society B: Biological Sciences 370:20140103.
Chapman, C. A., M. D. Wasserman, T. R. Gillespie, M. L. Speirs, M. J. Lawes, T. L. SAJ, AND T. E. Ziegler. 2006. Do nutrition, parasitism, and stress have synergistic effects on red colobus populations living in forest fragments? American Journal of Physical Anthropology 131:525-534.

Clarke, M. R., C. M. Crockett, E. L. Zucker, and M. Zaldivar. 2002. Población de aulladores mantos de Hacienda La Pacifica, Costa Rica, entre 1991 y 1998: efectos de la deforestación. American Journal of Primatology 56:155-163.

Cristóbal-Azkarate, J., B. Hervier, S. Vegas-Carrillo, D. OsorioSarabia, E. Rodríguez-Luna, and J. J. Veà. 2010. Infecciones parasitarias de tres grupos de monos aulladores mexicanos (Alouatta palliata mexicana) que viven en fragmentos de bosques en México. Primates 51:231-239.

Día, T. 2001. Modos de transmisión de parásitos y evolución de la virulencia. Evolución 55:2389-2400.

Eckert, K. A., N. E. Hahn, A. Genz, D. M. Kitchen, M. D. Stuart, G. A. Averbeck, B. E. Stromberg, and H. Markowitz. 2006. Coprological surveys of Alouatta pigra at two sites in Belize. International Journal of Primatology 27:227-238.

Freeland, W. J. 1980. Mangabey (Cercocebus albigena) movement patterns in relation to food availability and fecal contamination. Ecology 61:1297-1303.

Friant, S., T. E. Ziegler, and T. L. Goldberg. 2016. Primate reinfection with gastrointestinal parasites: behavioural and physiological predictors of parasite acquisition. Animal Behaviour 117:105-113.

Gilbert, K. A. 1997. Red howling monkey use of specific defecation sites as a parasite avoidance strategy. Animal Behaviour 54:451-455.

GILLESPIE, T. R. 2006. Noninvasive assessment of gastrointestinal parasite infections in free ranging primates. International Journal of Primatology 27:1129-1143.

Gillespie, T. R., ANd C. A. Chapman. 2008. Forest fragmentation, the decline of an endangered primate, and changes in host-parasite interactions relative to an unfragmented forest. American Journal of Primatology 70:222-230.

Gillespie, T. R., C. L. Nunn, AND F. H. Leendertz. 2008. Integrative approaches to the study of primate infectious disease: implications for biodiversity conservation and global health. American Journal of Physical Anthropology 51:53-69.

Godor, K., A. Odalia-Rímol, and J. Rímoli. 2004. Infecção por endoparasitas em um grupo de bugios-pretos (Alouatta caraya) em um fragmento florestal no Estado Do Mato Grosso Do Sul, Brasil. Neotropical Primates 12:63-68.

Habig, B., AND E. A. ArChiE. 2015. Social status, immune response and parasitism in males: a meta-analysis. Philosophical Transactions of the Royal Society B: Biological Sciences 370: 20140109.

Hudson, P. J., AND A. P. Dobson. 1997. Host-parasite processes and demographic consequences. Pp. 128-154, in Host-parasite evolution: General principles and avian models (Clayton, D. H., and J. Moore, eds.). Oxford University Press. Oxford, United Kingdom.

KLein, S. L. 2004. Hormonal and immunological mechanisms mediating sex differences in parasite infection. Parasite Immunology 26:247-264.

Kowalewski, M., AND G. E. Zunino. 2005. The parasite behavior hypothesis and the use of sleeping sites by black howler 
monkeys (Alouatta caraya) in a discontinuous forest. Neotropical Primates 13:22-26.

Kowalewski, M. M., AND T. R. Gillespie. 2009. Ecological and anthropogenic influences on patterns of parasitism in freeranging primates: a meta-analysis of the genus Alouatta. Pp. 433-461, in South American Primates. Comparative Perspectives in the Study of Behavior, Ecology and Conservation (Garber, P. A., A. Estrada, J. C. Bicca-Marques, E. W. Heymann, and K. B. Strier, eds.). Springer. New York, U.S.A.

Kowalewski, M. M., J. S. Salzer, J. C. Deutsch, M. Raño, M. S. Kuhlenschmidt, AND T. R. Gillespie. 2011. Black and gold howler monkeys (Alouatta caraya) as sentinels of ecosystem health: patterns of zoonotic protozoa infection relative to degree of human-primate contact. American Journal of Primatology 73:75-83.

Krasnov, B. R., M. Stanko, and S. Morand. 2006. Age-dependent flea (Siphonaptera) parasitism in rodents: a host's life history matters. Journal of Parasitology 92:242-248.

LLoyd, S. 1995. Environmental influences on host immunity. Pp. 327-361, in Ecology of infectious diseases in natural populations (Grenfell, B. T., and A. P. Dobson, eds.). Cambridge University Press. Cambridge, United Kingdom.

Macintosh, A. J. J., A. D. Hernandez, and M. A. Huffman. 2010. Host age, sex, and reproductive seasonality affect nematode parasitism in wild Japanese macaques. Primates 51:353-364.

Macintosh, A. J. J., A. Jacobs, C. García, K. Shimizu, K. Mouri, And M. A. Huffman. 2012. Monkeys in the middle: parasite transmission through the social network of a wild primate. PlosOne 7:e51144.

Maldonado-López, S., Y. Maldonado-López, A. Gómez-Tagle, P. Cuevas-Reyes, and K. E. Stoner. 2014. Patterns of infection by intestinal parasites in sympatric howler monkey (Alouatta palliata) and spider monkey (Ateles geoffroyi) populations in a tropical dry forest in Costa Rica. Primates 55:383-392.

Milozzi, C., G. Bruno, E. Cundom, M. D. Mudry, and G. T. Nanove. 2012. Intestinal parasites of Alouatta caraya (Primates, Ceboidea): preliminary study in semi-captivity and the wild in Argentina. Mastozoología Neotropical 19:271-278.

Muehlenbein, M. P., And D. P. Watts. 2010. Los costos de la dominancia: testosterona, cortisol y parásitos intestinales en chimpancés machos salvajes. BioPsychoSocial Medicine 4:21.

Muehlenbein, M. P., And R. G. Bribiescas. 2005. Funciones inmunes mediadas por testosterona e historias de vida masculina. American Journal of Human Biology 17:527-558.

Nunn, C., And S. Altizer. 2006. Infectious diseases in primates: Behavior, ecology and evolution. Oxford University Press. Oxford, United Kingdom.

Parr, N. A., L. M. Fedigan, And S. J. Kutz. 2013. Predictors of parasitism in wild white-faced capuchins (Cebus capucinus). International Journal of Primatology 34:1137-1152.

Plowright, R. K., H. E. Field, C. Smith, A. Divljan, C. Palmer, G, Tabor, P. Daszak, and J. E. Foley. 2008. Reproduction and nutritional stress are risk factors for Hendra virus infection in little red flying foxes (Pteropus scapulatus). Proceedings of the Royal Society B: Biological Sciences 275:861-869.

R Core Team. 2016. R: A language and environment for statistical computing. R for Statistical Computing, Vienna, Austria. URL https:// www.R-project.org/
Rumiz, D. I., G. E. Zunino, M. L. Obregozo, and J. C. Ruiz. 1986. Alouatta caraya: habitat and resource utilization in northern Argentina. Pp. 175-196, in Current perspectives in primate social dynamics (Taub, D. M., and F. A. King, eds.). Van Nostrand Reinhold. New York, U.S.A.

SAPolsky, R. M. 2005. The influence of social hierarchy on primate health. Science 308:648-652.

Setchell, J. M., I. Bedjabaga, B. Goossens, P. Reed, E. J. Wickings, AND L. A. KnApp. 2007. Parasite prevalence, abundance, and diversity in a semi-free-ranging colony of Mandrillus sphinx. International Journal of Primatology 28:1345-1362.

Stoner, K. E., And A. M. González Dı Pierro. 2006. Intestinal parasitic infections in Alouatta pigra in tropical rain forest in Lacandona, Chiapas, Mexico: implications for behavioral ecology and conservation. Pp. 215-240, in New perspectives in the study of Mesoamerican primates: distribution, ecology, behavior, and conservation (Estrada, A., P. A. Garber, M. S. M. Pavelka, and L. Luecke, eds.). Springer. New York, U.S.A. Stuart, M. D., ANd K. B. Strier. 1995. Primates and parasites: a case for a multidisciplinary approach. International Journal of Primatology 16:577-593.

Teichroeb, J. A., S. J. Kutz, U. Parkar, R. C. A. Thompson, and P. Sicotte. 2009. Ecology of the gastrointestinal parasites of Colobus vellerosus at Boabeng-Fiema, Ghana: possible anthropozoonotic transmission. American Journal of Physical Anthropology 140:498-507.

Trejo-Macías, G., AND A. Estrada. 2012. Risk factors connected to gastrointestinal parasites in mantled Alouatta palliata mexicana and black howler monkeys Alouatta pigra living in continuous and in fragmented rainforests in Mexico. Current Zoology 58:375-383.

Van Belle, S., and A. Estrada. 2006. Demographic features of Alouatta pigra populations in extensive and fragmented forests. Pp. 121-142, in New perspectives in the study of Mesoamerican primates. Distribution, ecology, behavior, and conservation (Estrada, A., P. A. Garber, M. S. M. Pavelka, and L. Luecke eds.). Springer. New York, U.S.A.

Venturini, L., A. M. Santa Cruz, A. J. González, A. J. Comolli, A. P. Toccalino, And G. E. Zunino. 2003. Presencia de Giardia duodenalis (Sarcomastigophora, Hexamitidae) en mono aullador (Alouatta caraya) de vida silvestre. Comunicaciones Científicas y Tecnológicas, Universidad Nacional del Nordeste. Corrientes, Argentina.

Vitazkova, S. K., and S. E. Wade. 2007. Effects of ecology on the gastrointestinal parasites of Alouatta pigra. International Journal of Primatology 28:1327-1343.

Zuk, M., AND A. Stoenr. 2002. Immune defense and host life history. The American Naturalist 160: S9-S22.

Zunino, G. E., M. M. Kowalewski, L. I. OKLander, and V. González. 2007. Habitat fragmentation and population size of the black and gold howler monkey (Alouatta caraya) in a semideciduous forest in northern Argentina. American Journal of Primatology 69:966-975.

Associated editor: Jesús Fernández

Submitted: March 15, 2020; Reviewed: April 12, 2020.

Accepted: June 18, 2021; Published on line: August 13, 2021. 
GIARDIA AND BLASTOCYSTIS IN A. CARAYA

570 THERYA Vol. $12(3): 563-569$ 